\title{
Current HIV Prevention Policies Are Jeopardizing the "End of AIDS" Project: Realities Counteract Liberal Visions
}

\author{
Reinhard H. Dennin \\ Department of Infectious Diseases and Microbiology, University of Luebeck, UKSH, Campus Luebeck, Luebeck, Germany \\ Email: reinhard.dennin@uk-sh.de
}

How to cite this paper: Dennin, R.H. (2017) Current HIV Prevention Policies Are Jeopardizing the "End of AIDS" Project: Realities Counteract Liberal Visions. World Journal of AIDS, 7, 138-156. https://doi.org/10.4236/wja.2017.72012

Received: June 1, 2017

Accepted: June 25, 2017

Published: June 29, 2017

Copyright $\odot 2017$ by author and Scientific Research Publishing Inc. This work is licensed under the Creative Commons Attribution International License (CC BY 4.0).

http://creativecommons.org/licenses/by/4.0/

\begin{abstract}
Here I discuss a series of in adequate decisions made by governments of, e.g., the European Union when designing strategies aimed at preventing the spread of human immunodeficiency virus (HIV). Although there have been minor successes in curbing the spread of HIV, here I focus on the multiple failings that have indirectly fostered the spread of HIV. I propose that a novel, programmatic set of strategies are needed to prevent the spread of HIV, which will be necessary to meet aims of the End of AIDS (acquired immunodeficiency syndrome) project. I also discuss barriers to the End of AIDS project, including financial burdens and noncompliance, in particular of the "at-risk" termed population in resource rich countries, with current prevention strategies. The aim is (i) to foster supporting for the UNAIDS project by customized prevention concepts; and (ii) to raise awareness for the challenges yet to come, should the UNAIDS project fail.
\end{abstract}

\section{Keywords}

HIV Prevention, New Public Health, Biomedical Approach, Human Behavior

\section{Introduction}

Since the advent of the human immunodeficiency virus/acquired immunodeficiency syndrome (HIV/AIDS) pandemic, to curb the spread of HIV, governments have developed bespoke strategies, campaigns, and concepts to fit their national, cultural and social needs.

The liberally structured prevention concepts are based mostly on the ideas of the New Public Health (NPH). A major message therein is "Instead of focused individual attention, an emphasis is placed on the population, with more tho- 
rough analysis of the social factors influencing health and disease, and the factors responsible for inequality" [1].

This includes: (i) general information about the routes of HIV transmission and some clinical aspects for the public at large have been provided; and (ii) the messages developed by the respective public health authorities for the HIV prevention concepts try to influence human behavior by applying a social learning strategy, aimed at encouraging the avoidance of risky lifestyles favorable to person-to-person transmission of HIV (e.g., unprotected anal intercourse/UAI, unsafe injection practices during drug use). Other factors posing a risk for acquiring HIV include lower socio-economic status, lower education, troubled teens, structural inequities, and culturally sensitive situations. Those have to be seen apart from the possibility of mother-to-child transmission, occupational infections and blood transfusion.

However, this approach is flawed because: the HIV transmission gets driven onwards by an individual behavior which is mainly guided by the emotional level, i.e., coined partly by cognitive dissonance and instinctively controlled by the sexual urge. Exclusively providing correct messages aimed at changing an ingrained behavior is not enough; solely deploying this strategy by just addressing the cognitive level was a wrong decision.

These strategies are basing on self-deceptions about people being unable to understand the messages and sub-populations (referred to as the at-risk group or key population) with selfish gained behavior. A proportion of the "most at-risk population" [2] might already suffer from cognitive restrictions caused by HIV infection of the central nervous system (CNS), which might be aggravated by the use of psychedelic drugs (see below).

These inadequate concepts lead to mistakes. For example, the same messages are given to adults (highly and poorly educated), teens, socially separated people, people with psychological disorders, and those with libidinal carvings likely to overriding any intellectual-based message.

Without exception, the prevention concepts base just on information, counseling distributed both by mass communication for the general population and rare individual counseling by specially trained services at different organizations, official ones, and Non-Government Organizations (NGO).

These liberal concepts allow unlimited autonomy for the individuals' self-determination and, therefore, overlook opportunities for forcing personal responsibility, as well as providing any sustained counseling. Thus, the designers and policy makers, who seemed to be insulated from real life settings, assume that the at-risk population will behave responsibly if informed. This assumes that the population uniformly understands and complies (less risky behavior) with the message. This is wrong. Indeed, the exact opposite result (more risky behavior) has been observed.

It is only in recent years that the idea of linking at-risk people to medical and social care services has gained acceptance. Thus, HIV testing rates have increased and, in the case of comorbidities, patients are better managed. 


\section{Interim Summary}

Since about 2003, the HIV prevention strategies are a combination of NPH concepts and antiretroviral therapy (ART). However, this appears to have been insufficient. The Global AIDS Update presented by UNAIDS (2016) states that, "2.1 million (...) people became newly infected with HIV (end 2015)" [3] (for more details see the chapter UNAIDS project 90:90:90).

With regard to the WHO's initiative on HIV prevention [4], the following statement lacks of pointing to the root causes on what is driving the HIV epidemic: "Despite all the efforts to fight HIV, this year the European Region has reached over 142,000 new HIV infections, the highest number ever. This is a serious concern" (in 2014) [5]. The same applies to the Political Declaration on Ending AIDS by the UN [6]. These trends have not changed yet [7]. The matter in question for 2015 reveals “... 153407 HIV infections newly diagnosed in 50 of the 53 countries of the WHO European Region in 2015 ...” [8]. Also:

"The data presented in this report indicate that, despite significant efforts dedicated to the prevention and control of HIV in Europe, the number of new HIV diagnoses has not declined substantially over the last decade in the western part of the Region and the EU/EEA, and has more than doubled in the East. In the Centre, while remaining at a low level overall, the number of new diagnoses has increased more than anywhere else in the Region" [9].

The same holds true according to a statement of the Conference on HIV: "Although there have been impressive gains in reducing the number of AIDS diagnoses during the last decade, the burden of HIV infection remains unacceptably high in Europe.(...).Europe is the region with the fastest growing rate of infection in the world. There is good evidence on what works to prevent and control HIV effectively. To reverse the HIV epidemic in the EU/EEA, countries need to scale up: (...)" [10].

Both statements don't point to the core causes behind the spreading of HIV. Given the continuing increase in HIV prevalence in the countries addressed the above-cited statements have disregarded the down-home realities of human behavior in particular of the at-risk people-also termed core or key population.

\section{What Went Wrong?}

Analysis about what went wrong must consider the 'direct barriers' and the repercussions/ramifications resulting from these.

Regarding the most affected people in certain areas and countries with comparable standards of education and health care: EU (West-and Central-EU): MSM followed by heterosexuals; the East-EU: injecting drug users (IDU) dominate; the USA: notably MSM, heterosexuals, IDU.

a. Autonomy for sexual laxity of any kind: In countries that follow this ruling it imparts free decisions for the benefits of individual risky lifestyles on account of the value-based community by following the modern trends of a selfishly guided individualism [11] (i.e., it lacks to claim everybody's responsiveness for partners and for the society).Instead, the political leaders give self-interestedness 
superior importance than the public interest.

b. This ruling worked to some degree for people willing to surrender to ethical rules and duties to the communities [12]. However, as already forecast in the late 1980s, this ruling for autonomy resulted in setbacks by indirectly legalizing misdemeanors (in particular of those at-risk people who are not willing to cooperate with prevention messages); furthermore, the limited impact of the campaigns at the beginning of the current prevention campaigns has eroded over time due to the waning awareness of real threats once infected; this is with regard to get the highly active antiretroviral therapy (HAART). Many of these radically different people pursued selfish lifestyles that are not compatible with HIV prevention campaigns. This doctrine indirectly fortified these developments and may now constitute barriers against the UNAIDS vision.

c. Apart from passing acquaintances on a case-by-case basis, casual partner encounters, private venues, new trends emerged out of the at-risk population: Concurrent partnerships [13] or overlapping partnerships, resp. in the context of high promiscuity; such settings potentially promote, e.g., blending of different HIV clades and future transmitted drug resistance (TDR) [14]. Also, there are these mass events where people gather to intentionally engage in drugs and sex with multiple partners [15]. These trends are supported by new technologies, such as "geosocial networking apps" [16]. Group settings of this kind may sub-serve cluster prone spreading of HIV, and in addition to it may promote rising rates of other sexual transmitted infections (STIs); and as soon as such people are diagnosed positive for HIV and other STIs, all of them will gain the status of claimants against the societies to ask for help. They permanently provide definitive evidence that the HIV prevention campaigns have failed in their fundamental goal to prevent risk-prone people from spreading HIV.

d. Furthermore, certain types of risky behaviors are potentiated by misusing psychedelic drugs, e.g., "Legal Highs" or illicit ones, resp., during settings termed such as "sex and drugs, chem-sex" [17] [18] [19]. In the context of the legalization of marijuana, its epigenetic fixed ramifications have to be considered [20]. When consuming short-and long-acting illicit drugs, cognitive control is limited and might result in loss of self-control, possibly leading to risky sex practices [21].

It is a well-known fact that, in settings of like-minded people, endogenous intrinsic binding rules dominate; by disobeying established law, these people follow their unwritten rules directed against societal consents and, consequently, foster the violation of the ideas of the Human Rights and social norms. Even more, forced by outside pressure, group dynamics empower the "team spirit", gain momentum, and thereby foster their seclusion from the society. Different subcultures with their own intrinsic collective identities may develop, which depend on their lifestyle practices addressed here with the consequence of breaking down yardsticks for law and their social dislocation; behavior of his kind is directed against the social conscience. Trends of this kind have developed their own dynamics and emerged into a particular kind of radicalization. They get 
promoted through the protective effect of HIV exceptionalism [22] [23] although HIV shares the same routes of transmission like other STIs, e.g., Hepatitis B Virus (HBV) and Hepatitis C Virus (HCV) (both HBV and HCV are blood-borne infections). HIV exceptionalism has indirectly increased the number of people unaware of their HIV infection. The ECDC estimates " 1 in 7 people living with HIV in the EU/EEA are not aware of their HIV status", see in [37]; many of them will not be tested as HIV-positive for many years, and might contribute to a substantial portion of HIV transmissions during their asymptomatic status. Thus, these people pose a public health hazard.

The fact is that all those responsible for HIV prevention campaigns have overlooked or intentionally neglected very basic knowledge of psychology: thus failing to counteracting the fault-tolerant behavior of people who spread HIV leads towards a negative learning effect to them; because there are no restrictions by law an attitude gained momentum such as: upholding risk-prone lifestyles has gained a dominating scale; tolerating such trends render legal systems helpless to act as a fundamental normative principle to correct human behavior.

\section{The Results Thereof}

Continuing with the rule of autonomy, engagement in risky sexual behaviors was increased by the availability of highly active antiretroviral therapy (HAART) at the end of the last century-and consequences thereof [24] [25] [26] [27]. HAART both impairs the HIV replication in most HIV-infected people thereby improving their immune status, and facilitating an increased life expectancy. In addition, an effective HAART renders them less infectious due to a low level or even down to a non-detectable HIV concentration in their blood (VL), thereby reducing the spread of HIV by interrupting essential shares of the chains of infections at the population level, in particular, within the high-risk communities. However, the messages about the effect of HAART on the infectiousness emerged such as a relief for those infected with HIV, i.e., to be rid of any coercion to follow safe sex rules-just in view of HIV. Again, trends of this kind reveal the limits of the current prevention strategies.

HAART is part of the treatment as prevention (TASP) strategy [28], and became part of the vision of UNAIDS to end AIDS. However, an inverse effect took place: by misusing its key advantages by too many of the at-risk people [29], its goal became partly offset. Rather than decreasing HIV prevalence, HIV"... continues to expand in most low, middle, and upper income countries" prevalence is increasing globally [30] [31]. Despite ongoing safe-sex and safe-use campaigns and the availability of HAART since the midst of the 1990's, the spread of HIV is ongoing, and the incidences of HIV are going up. Therefore, new policies have to show up limits against selfish behavior that supports the spread of HIV.

\section{What Needs to Be Changed?}

What needs to be changed? [32] The statement of representatives of the WHO, 
2015, as in [5] features the concession of the serious setbacks of the HIV prevention strategies for Europe. Subsuming the severe ramifications thereof for the societies, the disambiguating message is: to continue with the HIV prevention strategies only as before is an irresponsible perspective. The current ones, which are guided by the apprehension of a principled autonomy, have to call into question; it requires revision and customization regarding the future challenges targeting the people of the most hit age groups engaged in modern sexual laxity. Future strategies also have to prioritize measures for those people who will continue to intentionally ignore the current prevention messages (PM) in combination with the TASP strategy; in the interest of the societies, it is a legal approach forcing them to subordinate to the objective of the realization this UNAIDS project. PM have to be designed to focus on yet unconventional methods to support the UNAIDS 90:90:90 projects. In general: It is an urgent task to intensify information about the HIV infection itself, and to raise awareness both of risk perception and the various serious aftermaths of the HIV infection-even when living with HAART in the life-long perspective. It requires adherence to the prescriptions, compliance with the instructions-and responsiveness for partners and the societies. Based on study reports both categorical and deterrent messages have to be developed to make clear the dangerous consequences of unprotected intercourse (UI) and injecting drugs with contaminated paraphernalia even despite of HAART; UI has to be dammed as a serious misdemeanor. There are urgent claims for trying to modify the ingrained behavior of those at risk, in particular of the MSM in Europe and USA. However, the yet unsolved task is on how to intervene in real life scenarios expressed in "... Behavior beats Science" [33].

But messages of such kind finally have also to illustrate positive aspects when living without HIV.

\section{Interim Conclusions}

These indulged and unresolved issues pose direct barriers counteracting all endeavors to contain the spread of HIV. Policy decision makers should get a sobering impact regarding the mounting collateral damage to the communities resulting in extreme challenges for the societies in the long-term view that will last for decades-if they continue protecting people who insist on behavior which promotes the spread of HIV.

\section{UNAIDS Project 90:90:90: The Vision "End AIDS by 2030 [34]"}

The rationale of the UNAIDS 90:90:90 project bases on a biomedical HIV prevention strategy, i.e., the TASP strategy as an additional alternative in combination with improved prevention campaigns. The target goal is: “... the achievable target: By 2020, 90\% of all people living with HIV will know their HIV status. By 2020, 90\% of all people with diagnosed HIV infection will receive sustained antiretroviral therapy. By 2020, $90 \%$ of all people receiving antiretroviral therapy 
will have viral suppression."'The epidemiological facts the UNAIDS 90:90:90 project has to cope with are: "18.2 million [16.1 million - 19.0 million] people were accessing antiretroviral therapy (June 2016), 36.7 million [34.0 million 39.8 million] people globally were living with HIV (end 2015)" [35]. that is, about 18.5 million people are living without ART, and partly unaware of their HIV infection. UNAIDS itself already heralded warningly: "Without scale-up, the AIDS epidemic will continue to outrun the response, increasing the long-term need for HIV treatment and increasing future costs" [36]; and "If we take a look at the available data, we can see that Europe needs to improve its HIV response in several areas". (..) "Currently, two out of three EU/EEA countries tell us that they do not have sufficient funding for prevention interventions (...)" [37].

"There is mounting anxiety among the experts and the activists at this year's Durban International Aids Conference that the epidemic may slip out of control once more" [38]. A severe warning was also given at the IAS 2015 conference:"The world must act rapidly to drive down HIV incidence, death, and long-term costs. (...) We call on leaders the world over to implement HIV science and commit to providing access to immediate HIV treatment to all people living with HIV" [39].

Thus, it is clearly necessary to boost HIV testing. This raises the question: How to achieve the necessary impact on HIV-infected people to provide them with HAART?

a) The testing concept of the USPSTF should be applied [40] [41]. Essentially, political decision makers have to be reminded of having disregarded, and of the CDC “(...) traditional disease-control principles and proven interventions (...)", as in [22] from the first days of the HIV pandemic. The strategy of the USPSTF should remind decision makers to establish HIV testing as a regular practice; the exceptionalism of the HIV infection should be abandoned. This could involve intensifying testing regimes for high-risk group members. Also, testing regimes must include counseling adapted for key populations and include efforts to link HIV-negative (test repeats!) and HIV-positive tested people to medical care [42].

b) Community-based rapid HIV testing should be applied to reach marginalized people [43].

c) Outreach work should be extended to contact IDU in safe injection/consumption facilities to both help them (i) when changing needles, syringes, and (ii) also assist them by tailored counseling to get an HIV test and offering them support if tested HIV-positive.

d) Where existing, the non-disclosure habit/rule that allows HIV infected individuals not to inform a potential partner about their HIV status has to be questioned. The Technical Report of the ECDC clearly depicts the "...wide variety of partner notification practices in Europe" [44]. The particular psychological charges that entail the "non-disclosure" situations should be re-visited [45].

e) Policymaker must decide whether allowing the opting out of HIV testing sustains chains of HIV infection, thereby increasing the "community viral load", 
in particular in the at-risk settings which in turn may foster HIV transmission.

f) Intensifying back tracing on a voluntary basis to identify such index patients. This could involve consulting physicians when new cases are diagnosed. Those that test HIV-positive should be motivated to ask recent sex and drug partners to be tested.

g) If an individual tests HIV-positive, depending on the individual's personal circumstances, an HIV-VL test should follow, as well as a test for cART-resistance.

A consequence of lacking any comprehensive, reality-based concepts for the actual at-risk people and the newcomers for the risk communities might be: without any goal to integrate them back into the society, this kind of the "autonomy based" 'freedom' like "let them have their fun" will increasingly pave the way for the ongoing misuse of solidarity at the expense of strains for the societies (e.g., future services and costs for).

However, critics have stated that"... an analysis showing that donor funding for the HIV response in low- and middle-income countries declined by almost 13\% between 2014 and 2015" [45]; and a positive view "Global gains ..." [47]; disparities of 'antiretroviral therapy'between real world and clinical cohort trials reveal significant limitations regarding the recommended regimens [48], and difficulties regarding certain HIV testing strategies [49].

A report from the $15^{\text {th }}$ European AIDS Conference cited statements that show existing and possible barriers to the UNAIDS 90-90-90 targets [50]. Another report only focuses on the need of financial support by stating "There are now whole communities of survivors living longer and living with comorbidities ..." [51]. Despite expected future problems, there are favorable reports from resource-rich countries, such as Sweden [52], the USA (San Francisco) [53], and the United Kingdom [54].

\section{What's Lurking in This Context?}

Two potential future scenarios: 1) The UNAIDS 90:90:90 project works as expected (Scenario 1); or 2) The UNAIDS 90:90:90 project fails (Scenario 2) [55].

\subsection{Scenario 1-What Would Be the Result?}

Is this a realistic vision? Because there are imperceptibly calculable issues posing challenges to the society's specialties. The demand for covering the costs for the people receiving CART might last for several decades due to their longer lifetime. There are already considerations on how to manage the costs [56] [57]. Therefore, it is necessary to make aware those responsible for health care and social services in that they have to consider the additional costs for treatment the comorbidities too-a large part of them are due to STIs derived ones which have been acquired via shared routes of transmission of HIV.

In addition to the current situations, with barriers already in place as a consequence of the liberal structured prevention campaigns which others ones are to be expected with the potential of a failure of Scenario 1? 
Some selected serious aspects are: (i) Uncertainties regarding the concept of TASP in real world settings [58]; this is with eminent regard to the adherence to cART [59] in the short and the life-long term, i.e., decades, and the increasing problems with ART-resistant HIV [60] [61]; (ii) the ongoing no-cooperation attitudes of the at-risk hardliner/population-MSM followed by heterosexuals-and injecting drug users with respect to European countries [62]; decision makers at the political levels should be aware of the complacency effect of those people receiving HAART: it is to be expected that a portion of them remain infectious to partners and unconcernedly continue risky practices; in the context of not being able to evaluate remaining risks; (iii) the contribution of spreading HIV by "unreasonable regular and other travelers belonging to a higher risk class of people [63] [64]"; (iv) the ongoing spread of HIV in Central Europe unaffected by prevention campaigns [65]; (v) the social problems of lost people in long-term HIV care [66]; concomitantly, the UNAIDS project can gain support by the pre-exposure (PrEP) strategy at the first glance. However, it shows the same "side effects" as with the TASP strategy: complacency and carelessness seduced too many of them to follow risky practices (e.g., unprotected intercourse, resulting in increasing rates of HCV, as well as other STIs) [67].

The potential of these issues expresses concern; the message hereof is: the UNAIDS project needs urgent support by devising appropriate prevention concepts provided with framing restraints which must have allocative functions. Regarding this background, doubts are justified whether the vision of UNAIDS may reach its goal.

\subsection{Scenario 2-The Perpetuation of the HIV Pandemic?}

Political decision makers must address the question of whether the current prevention strategies are adequate. Based on bad experiences in the past, new concepts must be developed to tackle the yet tolerated ignorance of the current prevention concepts by too many people. Many of these details are similar to those described above but some additional points are raised below.

As well as the costs associated with ART and issues regarding drug resistance (DR) and transmitted drug resistance (TDR), there are other costs associated with the longer life expectancy of HIV-positive individuals; including hospitalization for entirely different reasons than their HIV infection [68] [69].

A substantial proportion of patients receiving ART will have an HIV-VL that is not sufficiently suppressed. Such individuals, that now have an extended live expectancy, might pose a serious potential to spread the HIV infection through risky behavior.

Also, as already forecasted, it should be noted that HIV is evoluting [70], which is being expedited by human behavior. This has to be seen in the context of people both unaware of their HIV infection with elevated infectiousness and those living with HIV under HAART partly spreading ART-resistant variants. Additionally, the spread of HIV-1 non-B subtypes [71] [72] and the blending of different HIV clades has resulted in circulating recombinant forms (CRFs). [73] 
[74]. CRFs can be generated if, for example, two HIV belonging to different clades super infect the same cells of a doubly infected individual. During the replicative cycle, the HIV genome encoded reverse transcriptase can recombine genetic sections from these genotypical different HIVs and might generate a replicative CRF that can be subsequently transmitted. Clusters of at-risk populations enjoying promiscuity have been termed "recombinant hot spots". The upcoming CRFs reveal the international blending of HIV-1 clades pushed forward by people counteracting the current prevention campaigns [75] [76]. Phylogeographic analyses have revealed the ongoing evolution of HIV as a result of human migratory flows [77]. Further aspects of a diversification of HIV concern the controllers [78] and the "viremic non-progressors VNP" [79], who live asymptomatically with the HIV (i.e., without yet being diseased from; but with the potential to spread HIV). Similarities with the situation in Chimpanzees infected with the simian immunodeficiency virus $\left(\mathrm{SIV}_{\mathrm{cpz}}\right)$ but relatively resistant to the establishment of an immune defect should possibly be a warning regarding "humankind's future" [80].

HIV infection of the CNS has gained an exceptional importance. The CNS is accepted as a reservoir for HIV with the potential for "systemic reseeding", and there are indications that, cART treatment is unable to eliminate the CNS sequelae of HIV infection [81]. HIV-associated neurological deficits may range from mild mental disorders with cognitive impairments to severe neuropsychological diseases. Once infected, the infection of the CNS with HCV also has the potential to cause neurocognitive impairments [82]. In the case of HIV/HCV coinfection of the CNS, neurological disorders might be aggravated [83] [84]; this is to be seen with special concern of the HCV reinfection scenarios [85]. Such situations might result in a higher rate of unemployment for those living with HIV [86]. Although sparsely reported at present, such cases might add up due to their longer life expectancy and will require increased hospitalization and medical care, thus increasing costs for treatment and welfare.

Additional charges for the health care system will increase because of the almost overlooked epidemics caused by other STIs, such as HCV [87] [88] [89]. There are 177.5 million HCV-infected adults worldwide [90]; in particular, the following aspects have to be addressed here: the shared routes of HCV and HIV transmission in the wake of traumatizing unprotected sexual intercourse have to be seen in the context of HCV in the rectal fluid of HIV/HCV co-infected MSM [91]-as a consequence of worry-free attitudes when trusting on HAART once infected, but not observing the messages of the prevention campaigns [92]. The transmission of HCV extends for injecting drug users when sharing blood contaminated paraphernalia.

These trends have been long-known about, but are not yet considered by Public Health policy makers, as indicated by the increasing incidences of syphilis by transmission routes shared with HIV [93] [94] [95] [96].

For those HIV-infected people under HAART, various diseases, e.g., Cardiovascular Diseases (CHD) [97] [98], and cancers, such as Non-AIDS-Defining 
Cancers [99], have been described that will need additional medical care about their extended life.

"We have reached a decisive moment for the nation" (...) "STD rates are rising, and many of the country's systems for preventing STDs have eroded. We must mobilize, rebuild and expand services-or the human and economic burden will continue to grow" [100].

The dilemma with tuberculosis in general [101] and particular in developing countries (e.g., South Africa's XDR-TB epidemic) is due to transmission rather than the evolution of resistant strains [102].

\section{Conclusions}

1) The development of the HIV epidemic in the EU demonstrates that the current policies have failed to curb the incidences of HIV infection and halt self-supporting chains of infections;

2) The at-risk population, as in [2] are most affected;

3) Therefore, political decision makers and proponents of the liberal concepts are confronted with a large at-risk population and continued non-compliant behavior;

4) The current prevention campaigns are fraught with insufficiencies;

5) Continuing them furthermore, the hard-edged prospect is: the at-risk "subculture" population and other people being prone to spontaneous risk engagement of any kind will not behave cooperatively with the correct prevention messages for different reasons and may perpetuate the HIV epidemics.

6) These people have the potential to boycott the UNAIDS-Project with yet inestimable financial burden for decades in the future to cover the medical and social care systems. If these trends continue, the social stability of these communities is at risk.

7) To foster support for the UNAIDS project, and to forestall the worst case Scenario 2: apart from customizing current prevention concepts to reach the communities in general, the largest share of may not exhibit "high risk" attitudes in the context covered here, it is inalienable to design alternative multisector approaches: i) new incentives must be able to reach the prevention resistant parts of the key population; and ii) they must include messages enforcing individual cooperation and responsibility for partners and the value-based communities.

8) A project is needed that analyzes elements of the various multisectoral barriers; this is to select and compile evidence based results on a coordinated, comprehensive strategy with nationally adapted concepts. To avoid overlapping, possibly also opposing elements it should be guided by a supranational, politically independent institution.

9) If the obstacles addressed are not solved effectively soon, the HIV pandemic might become an unmanageable situation.

\section{References}

[1] Rosenbrock, R. (2001) Was ist New Public Health? (English Abstract). Bundesge- 
sundheitsbl - Gesundheitsforsch - Gesundheitsschutz, 44, 753-762.

[2] WHO (2011) Global Health Sector Strategy on HIV/AIDS 2011-2015. http://whqlibdoc.who.int/publications/2011/9789241501651_eng.pdf

[3] UNAIDS (2016) Global HIV Statistics. Fact Sheet November 2016. http://www.unaids.org/sites/default/files/media_asset/UNAIDS_FactSheet_en.pdf

[4] WHO (2011) Global Health Sector Strategy on HIV/AIDS 2011-2015. http://www.who.int/hiv/pub/hiv_strategy/en/

[5] WHO (2015) Highest Number of New HIV Cases in Europe Ever. 26 November 2015.

http://www.euro.who.int/en/media-centre/sections/press-releases/2015/11/highestnumber-of-new-hiv-cases-in-europe-ever

[6] United Nations, New York, Press Release (2016) Bold New Political Declaration on Ending AIDS Adopted in New York.

http://www.unaids.org/en/resources/presscentre/pressreleaseandstatementarchive/2 016/june/20160608_political-declaration

[7] Pharris, A., Quinten, C., Noori, T., Amato-Gauci, A.J. and van Sighem, A., the ECDC HIV/AIDS Surveillance and Dublin Declaration Monitoring Networks (2016) Estimating HIV Incidence and Number of Undiagnosed Individuals Living with HIV in the European Union/European Economic Area 2015. Euro Surveill, 21, pii $=30417$.

[8] European Centre for Disease Prevention and Control/WHO Regional Office for Europe (2016) HIV/AIDS Surveillance in Europe 2015. ECDC, Stockholm.

http://www.euro.who.int/_data/assets/pdf_file/0019/324370/HIV-AIDS-surveillan ce-Europe-2015.pdf

[9] WHO (2016) HIV/AIDS Surveillance in Europe 2015.

http://www.euro.who.int/en/health-topics/communicable-diseases/hivaids/publicati ons/2016/hivaids-surveillance-in-europe-2015-2016

[10] Conference on HIV-Co-Organised with the European Centre for Disease Prevention and Control (ECDC), Malta. HIV Conference Organized in Collaboration with the ECDC (2017) Fast-Track the End of AIDS in the EU - Practical Evidence-Based Interventions.

https://www.eu2017.mt/en/Events/Pages/Conference-on-HIV---Co-organised-with -the-European-Centre-for-Disease-Prevention-and-Control-(ECDC).aspx

[11] Beck, U. (1992) Risk Society: Towards a New Modernity. Sage, London.

Beck, U. (1986) Risikogesellschaft, Auf dem Weg in eine andere Moderne Taschenbuch. Edition Suhrkamp, Frankfurt. (In German)

[12] Rangel, J.C. and Adam, B.D. (2014) Everyday Moral Reasoning in the Governmentality of HIV Risk. Sociology of Health and Illness, 36, 60-74. https://doi.org/10.1111/1467-9566.12047

[13] Pines, H.A., Wertheim, J.O., Liu, L., Garfein, R.S., Little, S.J. and Karris, M.Y. (2016) Concurrency and HIV Transmission Network Characteristics among MSM with Recent HIV Infection. AIDS, 30, 2875-2883. https://doi.org/10.1097/QAD.0000000000001256

[14] Dai, L., Mahajan, S.D., Sykes, D.L., Shon, A., Schwartz, S.A., et al. (2014) Prevalence of Transmit-Ted HIV-1 Drug Resistance (TDR) Associated Mutations and Predicted Drug Sensitivity in Newly Diagnosed HIV-1 Patient Cohort in a Western New York, 2005-2011. Journal of Antivirals and Antiretrovirals, 6, 22-27.

[15] Dennin, R.H. (2016) HIV and Other STI Public Prevention Campaigns: Vain Endeavors to Break Risky New Trends in View of Blending Sex and Drugs. Progress in 
Health Sciences, 6, 158-164.

[16] Rhoton, J., Wilkerson, J.M., Mengle, S., Patankar, P., Rosser, B.R.S. and Ekstrand, M.L. (2016) Sexual Preferences and Presentation on Geosocial Networking Apps by Indian Men Who Have Sex with Men in Maharashtra. JMIR mHealth and uHealth, 4, e120. https://mhealth.jmir.org/2016/4/e120/ https://doi.org/10.2196/mhealth.5600

[17] Moncrieff, M. (2016) The ChemSex Phenomenon. European ChemSex Forum, London. https://pt.slideshare.net/Checkpoints14/the-chemsex-phenomenon

[18] Bourne, A., Reid, D., Hickson, F., Torres Rueda, S. and Weatherburn, P. (2014) The Chemsex Study: Drug Use in Sexual Settings among Gay \& Bisexual Men in Lambeth, Southwark \& Lewisham. Sigma Research, London School of Hygiene \& Tropical Medicine, London. http://researchonline.lshtm.ac.uk/2197245/

[19] Sewell, J., Miltz, A., Lampe, F.C., Cambiano, V., Speakman, A., Phillips, A.N., Stuart, D., Gilson, R., Asboe, D., Nwokolo, N., Clarke, A., Collins, S., Hart, G., Elford, J. and Rodger, A.J., Attitudes to and Understanding of Risk of Acquisition of HIV (AURAH) Study Group (2017) Poly Drug Use, Chemsex Drug Use, and Associations with Sexual Risk Behaviour in HIV-Negative Men Who Have Sex with Men Attending Sexual Health Clinics. International Journal of Drug Policy, 43, 33-43. https://doi.org/10.1016/j.drugpo.2017.01.001

[20] Callier, V. (2017) The Epigenetics of Marijuana Use. BioTechniques, The International Journal for Life Science Method, 7. http://www.biotechniques.com/news/365748

[21] Brack, J. (2016) Existing Well Known and New Psychoactive Illicit Drugs with a Broad Ranging Hazardous Potential. A Detailed Report on One's Experiences. Progress in Health Sciences, 6, 197-200.

[22] Frieden, R.Th., Das-Douglas, M., Kellerman, S.E. and Henning, K.J. (2005) Applying Public Health Principles to the HIV Epidemic. The New England Journal of Medicine, 353, 2397-2402. https://doi.org/10.1056/NEJMsb053133

[23] Bayer, R. and Fairchild, A.L. (2006) Changing the Paradigm for HIV Testing-The End of Exceptionalism. The New England Journal of Medicine, 355, 647-649. https://doi.org/10.1056/NEJMp068153

[24] Teeraananchai, S., Kerr, S.J., Amin, J., Ruxrungtham, K. and Law, M.G. (2017) Life Expectancy of HIV-Positive People after Starting Combination Antiretroviral Therapy: A Meta-Analysis. HIV Medicine, 18, 256-266. https://doi.org/10.1111/hiv.12421

[25] Marcus, J.L., Chao, Ch., Leyden, W., Xu, L., Quesenberry, Ch.P., Klein, D.B. Towner, W.J., Horberg, M.A. and Silverberg, M.J. (2016) Narrowing the Gap in Life Expectancy for HIV+ Compared with HIV- Individuals. Conference on Retroviruses and Opportunistic Infections (CROI), Boston, 22-25 February 2016, Abstract No. 54.

[26] Stolte, I.G., de Wit, J.B., van Eeden, A., Coutinho, R.A. and Dukers, N.H. (2004) Perceived Viral Load, but Not Actual HIV-1-RNA Load, Is Associated with Sexual Risk Behaviour among HIV-Infected Homosexual Men. AIDS, 18, 1943-1949. https://doi.org/10.1097/00002030-200409240-00010

[27] Bezemer, D., de Wolf, F., Boerlijst, M.C., van Sighem, A., Hollingsworth, T.D., Prins, M., Geskus, R.B., Gras, L., Coutinho, R.A. and Fraser, C. (2008) A Resurgent HIV-1 Epidemic among Men Who Have Sex with Men in the Era of Potent Antiretroviral Therapy. AIDS, 22, 1071-1077. https://doi.org/10.1097/QAD.0b013e3282fd167c

[28] Vernazza, P., Hirschel, B., Bernasconic, E. and Flepp, M. (2008) HIV-infizierte 
Menschen ohne andere STD sind unter wirksamer antiretroviraler Therapie sexuell nicht infektiös. Schweizerische Ärztezeitung, 89, 165-169.

https://doi.org/10.4414/saez.2008.13252

[29] Haar, K. and Amato-Gauci, A.J. (2015) European Men Who Have Sex with Men Still at Risk of HIV Infection Despite Three Decades of Prevention Efforts. Eurosurveillance, 20, pii $=21087$.

http://www.eurosurveillance.org/ViewArticle.aspx?ArticleId=21087 https://doi.org/10.2807/1560-7917.es2015.20.14.21087

[30] Beyrer, Ch., Sullivan, P., Sanchez, J., Barfal, S.D., Collins, Ch., Wirtz, A.L., Altman, D., Trapence, G. and Mayer, K. (2013) The Increase in Global HIV Epidemics in MSM. AIDS, 27, 2665-2676. https://doi.org/10.1097/01.aids.0000432449.30239.fe

[31] Beyrer, Ch., Baral, St.D., Collins, Ch., Richardson, E.T., Sullivan, P.S., Sanchez, J., Trapence, G., Katabira, E., Kazatchkine, M., Ryan, O., Wirtz, A.L. and Mayer, K.H. (2016) The Global Response to HIV in Men Who Have Sex with Men. The Lancet, 388, 198-206.

http://www.thelancet.com/pdfs/journals/lancet/PIIS0140-6736(16)30781-4.pdf

[32] Sewell, J., Speakman, A., Phillips, A.N, Cambiano, V., Lampe, F.C., Gilson, R., Asboe, D., Nwokolo, N., Clarke, A., Ogilvy, A., Collins, S. and Rodger, A.J. (2016) Attitudes to and Understanding of Risk of Acquisition of HIV over Time: Design and Methods for an Internet-Based Prospective Cohort Study among UK Men Who Have Sex with Men (the AURAH2 Study). JMIR Research Protocols, 5, e128.

[33] Mor, Z. and Dan, M. (2012) The HIV Epidemic among Men Who Have Sex with Men-Behaviour Beats Science. EMBO Reports, 13, 948-953.

https://doi.org/10.1038/embor.2012.152

[34] UNAIDS (2014) 90-90-90, An Ambitious Treatment Target to Help End the AIDS Epidemic. http://www.unaids.org/sites/default/files/media_asset/90-90-90_en.pdf

[35] UNAIDS (2016) Fact Sheet November 2016. Global HIV Statistics. http://www.unaids.org/sites/default/files/media_asset/UNAIDS_FactSheet_en.pdf

[36] UNAIDS (2014) Fast-Track: Ending the UNAIDS Report by 2030. http://www.unaids.org/sites/default/files/media_asset/JC2686_WAD2014report_en. pdf

[37] ECDC (2017) Reversing the HIV Epidemic: Europe Needs to Scale-Up Prevention, Testing and Treatment.

http://ecdc.europa.eu/en/press/news/_layouts/forms/News_DispForm.aspx?ID=153 8\&List $=8 \mathrm{db} 7286 \mathrm{c}-\mathrm{fe} 2 \mathrm{~d}-476 \mathrm{c}-9133-18 \mathrm{ff} 4 \mathrm{cb} 1 \mathrm{~b} 568$

[38] Boseley, S. (2016) HIV/Aids Resurgence in Africa Feared as Durban Hosts Conference. The Guardian, 18 July.

https://www.theguardian.com/society/2016/jul/18/south-africa-hosts-aids-conferen ce-as-experts-warn-of-stalled-progress

[39] The Vancouver Consensus, 21 July 2015 by SHARE Administrator, 8th International AIDS Conference on HIV Pathogenesis, Treatment and Prevention, Vancouver, 19-22 July 2015. https://www.hivsharespace.net/resource/vancouver-consensus

[40] US Preventive Services Task Force (USPSTF) (2013) Human Immunodeficiency Virus (HIV) Infection: Screening. http://www.uspreventiveservicestaskforce.org/uspstf13/hiv/hivfinalrs.htm

[41] Centers for Disease Control and Prevention (CDC) 24/7 (2016) CDC Guidance on HIV Testing in Nonclinical Settings.

https://effectiveinterventions.cdc.gov/en/HighImpactPrevention/PublicHealthStrate gies/HIVTesting.aspx 
[42] Howarth, A.R., Burns, F.M., Apea, V., Jose, S., Hill, T., Delpech, V.C., Evans, A., Mercer, C.H., Michie, S., Morris, S., Sachikonye, M. and Sabin, C., The REACH Study, and The UK Collaborative HIV Cohort (UK CHIC) Study (2017) Development and Application of a New Measure of Engagement in Outpatient HIV Care. HIV Medicine, 18, 267-274. https://doi.org/10.1111/hiv.12427

[43] Buchér, J.B., Thomas, K.M., Guzman, D., Riley, E., Dela Cruz, N. and Bangsberg, D.R. (2007) Community-Based Rapid Testing in Homeless and Marginally Housed Adults in San Francisco. HIV Medicine, 8, 28-31. https://doi.org/10.1111/j.1468-1293.2007.00423.x

[44] European Centre for Disease Prevention and Control (2013) Public Health Benefits of Partner Notification for Sexually Transmitted Infections and HIV. ECDC, Stockholm.

[45] Daskalopoulou, M., Lampe, F.C., Sherr, L., Phillips, A.N., Johnson, M.A., Gilson, R., Perry, N., Wilkins, E., Lascar, M., Collins, S., Hart, G., Speakman, A. and Rodger, A.J., For the ASTRA Study Group (2017) Non-Disclosure of HIV Serostatus and Associations with Psychological Factors, ART Non-Adherence, and Viral Load Non-Suppression among People Living with HIV in the UK. AIDS and Behavior, 21, 184-195. https://doi.org/10.1007/s10461-016-1541-4

[46] Health Gap, Global Access Project (September 2016) Separating Myths from Facts: Donor Funding for the HIV Response.

http://www.healthgap.org/hiv_donor_funding_myths_and_facts

[47] UNAIDS (2016) Global Gains Made towards the 90-90-90 Targets. http://www.unaids.org/en/resources/presscentre/featurestories/2016/july/20160717 $90-90-90$

[48] Smith, M., North American Correspondent, MedPage Today (October 2015) Sobering Results from Real World HIV Treatment Analysis-Clinical Trials Paint Rosy Picture but Not All Patients Do as Well. http://www.medpagetoday.com/MeetingCoverage/IDWeek/54016

[49] Habiyambere, V., Ford, N., Low-Beer, D., Nkengasong, J., Sands, A., Pérez González, M., et al. (2016) Availability and Use of HIV Monitoring and Early Infant Diagnosis Technologies in WHO Member States in 2011-2013: Analysis of Annual Surveys at the Facility Level. PLoS Medicine, 13, e1002088. https://doi.org/10.1371/journal.pmed.1002088

[50] Frellik, M. (2015) Europe Struggles to Meet UNAIDS 90-90-90 HIV Targets. 15th European AIDS Conference. http://www.medscape.com/viewarticle/853076

[51] Hein, I. (2016) 90-90-90 HIV Goals Top-of-Mind at Geneva Summit. Controlling the HIV Epidemic with Antiretrovirals Summit, Geneva, 13-14 October 2016. http://www.medscape.com/viewarticle/870127\#vp_2

[52] Gisslén, M., Svedhem, V., Lindborg, L., Flamholc, L., Norrgren, H., Wendahl, S., Axelsson, M. and Sönnerborg, A. (2017) Sweden, the First Country to Achieve the Joint United Nations Programme on HIV/AIDS (UNAIDS)/World Health Organization (WHO) 90-90-90 Continuum of HIV Care Targets. HIV Medicine, 18, $305-$ 307.

[53] Weber, S. and Buchbinder, S., (2016) The Getting to Zero San Francisco Consortium: Early Results. 21 st International AIDS Conference, Durban, South Africa. http://programme.aids2016.org/Abstract/Abstract/2903

[54] Whitlock, G., Blackwell, S., Carbonell, M., Patel, S., Suchak, T., Mohabeer, M., Toby, M., Barber, T., Nwokolo, N. and McOwan, A. (2017) Rapid Initiation of Antiretroviral Treatment in Newly Diagnosed HIV: Experience of a Central London Clinic. British HIV Association Conference, Abstract O14, Liverpool. 
[55] Boseley, S. (2016) Think the Aids Epidemic Is Over? Far from It-It Could Be Getting Worse.

https://www.theguardian.com/global-development/2016/jul/31/aids-epidemic-getti ng-worse-drug-resistance-cost

https://www.theguardian.com/global-development/2016/jul/31/aids-could-spiral-ou t-control-africa-again-experts-warn

[56] Vandewalle, B., Llibre, J.M., Parienti, J.-J., Ustianowski, A., Camacho, R., Smith, C., Miners, A., Ferreira, D. and Félix, J. (2016) EPICE-HIV: An Epidemiologic CostEffectiveness Model for HIV Treatment. PLoS ONE, 11, e0149007. https://doi.org/10.1371/journal.pone.0149007

[57] Musenge, E. (2016) A Cost-Effective and Focused Model for HIV Prevention. The Lancet HIV, 3, e402-e403. https://doi.org/10.1016/s2352-3018(16)30057-1

[58] Oldenburg, C.E., Bärnighausen, T., Tanser, F., Iwuji, C.C., De Gruttola, V., Seage, G.R., Mimiaga, M.J., Mayer, K.H., Pillay, D. and Harling, G. (2016) Antiretroviral Therapy to Prevent HIV Acquisition in Serodiscordant Couples in a Hyperendemic Community in Rural South Africa. Clinical Infectious Diseases, 63, 548-554. https://doi.org/10.1093/cid/ciw335

[59] Castillo-Mancilla, J.R., Brown, T.T., Erlandson, K.M., Palella Jr., F.J., Gardner, E.M., Macatangay, B.J.C., Breen, E.C., Jacobson, L.P., Anderson, P.L. and Wada, N.I. (2016) Suboptimal cART Adherence Is Associated with Higher Levels of Inflammation Despite HIV Suppression. Clinical Infectious Diseases, 63, 1661-1667. https://doi.org/10.1093/cid/ciw650

[60] Boender, T.S., Kityo, C.M., Boerma, R.S., Boerma, R.S., Hamers, R.L., Ondoa, P., Wellington, M., Siwale, M., Nankya, I., Kaudha, E., Akanmu, A.S.,. Botes, M.E., Steegen, K., Calis, J.C.J., de Wit, T.F.R. and Sigaloff, K.C.E. (2016) Accumulation of HIV-1 Drug Resistance after Continued Virological Failure on First-Line ART in Adults and Children in Sub-Saharan Africa. Journal of Antimicrobial Chemotherapy, 71, 2918-2927.

[61] Karade, S., Ghata, M., Chaturbhuj, D. and Gangakhedkar, R.R. (2016) CrossSectional Study of Virological Failure and Multinucleoside Reverse Transcriptase Inhibitor Resistance at 12 Months of Antiretroviral Therapy in Western India. Medicine, 95, e4886. https://doi.org/10.1097/MD.0000000000004886

[62] European Centre for Disease Prevention and Control (2015) ECDC GUIDANCE, HIV and STI Prevention among Men Who Have Sex with Men. Stockholm.

[63] Matteelli, A. and Capone, S. (2016) The Holy Grail of Prevention of Sexually Transmitted Infections in Travelers. Sexually Transmitted Infections, 92, 405-406. https://doi.org/10.1136/sextrans-2016-052573

[64] Gama, A., Abecasis, A., Pingarilho, M., Mendão, L., Martins, M.O., Barros, H. and Dias, S. (2016) Cruising Venues as a Context for HIV Risky Behavior among Men Who Have Sex with Men. Archives of Sexual Behavior, 46, 1061-1068.

[65] Gökengin D., Oprea, C., Uysal, S. and Josip, B. (2016) The Growing HIV Epidemic in Central Europe: A Neglected Issue? Journal of Virus Eradication, 2, 156-161.

[66] Lee, M., Rayment, M., Scourfield, A. and Gazzard, B. (2013) Comparison of Two Cohorts of Patients Presenting with AIDS: Patients with Previously Known HIV Diagnoses and True Late Presenters. Sexually Transmitted Infections, 89, 553-556. https://doi.org/10.1136/sextrans-2012-050966

[67] Midgley, L., Filson, S.A., Pearson, P., Ghosh, I. and Waters, L. (2017) Acute Hepatitis C Infection in Lower Risk MSM: An Evolving Picture. 23rd Annual Conference of the British HIV Association, Liverpool, 4-7 April 2017, British HIV Association Conference, Abstract No. 24, Liverpool. 
http://www.natap.org/2017/HCV/041717_01.htm

[68] Moore, C.L., Grulich, A.E., Prestage, G., Gidding, H.F., Jin, F., Petoumenos, K., Zablotska, I.B., Poynten, I.M., Mao, L., Law, M.G. and Amin, J. (2016) Hospitalisation for Anxiety and Mood Disorders in HIV-Infected and -Uninfected Gay and Bisexual Men. Journal of Acquired Immune Deficiency Syndromes, 73 , 589-597. https://doi.org/10.1097/QAI.0000000000001147

[69] Michel, L., Lions, C., Winnock, M., Lang, J.-P., Loko, M.-A., Rosenthal, E., Marchou, B., Valantin, M.-A., Morlat, P., Roux, P., Sogni, P., Spire, B., Poizot-Martin, I., Lacombe, K., Lascoux-Combe, C., Duvivier, C., Neau, D., Dabis, F., Salmon-Ceron, D. and Carrieri, M.P. (2016) Psychiatric and Substance Use Disorders in HIV/Hepatitis C Virus (HCV)-Coinfected Patients: Does HCV Clearance Matter? HIV Medicine, 17, 758-765. https://doi.org/10.1111/hiv.12382

[70] Baltimore, D. (1995) The Enigma of HIV Infection. Cell, 82, 175-176.

https://doi.org/10.1016/0092-8674(95)90303-8

[71] Dauwe, K., Mortier, V., Schauvliege, M., Van Den Heuvel, A., Fransen, K., Servais, J.-Y., Bercoff, D.P., Seguin-Devaux, C. and Verhofstede, Ch. (2015) Characteristics and Spread to the Native Population of HIV-1 Non-B Subtypes in Two European Countries with High Migration Rate. BMC Infectious Diseases, 15, 524. https://doi.org/10.1186/s12879-015-1217-0

[72] Beloukas, A., Psarris, A., Giannelou, P., Kostaki, E., Hatzakis, A. and Paraskevis, D. (2016) Molecular Epidemiology of HIV-1 Infection in Europe: An Overview. Infection, Genetics and Evolution, 46, 180-189.

[73] Hemelaar, J., Gouws, E., Ghys, P.D. and Osmanow, S. (2011) Global Trends in Molecular Epidemiology of HIV-1 during 2000-2007. AIDS, 25, 679-689. https://doi.org/10.1097/QAD.0b013e328342ff93

[74] Alexiev, I., Dimitrova, R., Gancheva, A., Kostadinova, A., Stoycheva, M., Nikolova, D. and Elenkov, I. (2016) HIV-1 Diversity in Bulgaria (Current Molecular Epidemiological Picture). BMC Infectious Diseases, 16, O1.

[75] Paraskevis, D., Nikolopoulos, G.K., Magiorkinis, G., Hodges-Mameletzis, I. and Hatzakis, A. (2016) The Application of HIV Molecular Epidemiology to Public Health. Infection, Genetics and Evolution, 46, 159-168.

[76] Hemelaara, J., Gouwsb, E., Ghysb, P.D. and Osmanova, S. (2006) Global and Regional Distribution of HIV-1 Genetic Subtypes and Recombinants in 2004. AIDS, 20, W13-W23. https://doi.org/10.1097/01.aids.0000247564.73009.bc

[77] González-Alba, J.M., Holguín, A., Garcia, R., García-Bujalance, S., Alonso, R., Suárez, A., Delgado, R., Cardeñoso, L., González, R., García-Bermejo, I., Portero, F., de Mendoza, C., González-Candelas, F. and Galán, J.C. (2011) Molecular Surveillance of HIV-1 in Madrid, Spain: A Phylogeographic Analysis. Journal of Virology, 85, 10755-10763. https://doi.org/10.1128/JVI.00454-11

[78] de Azevedo, S.S.D., Caetano, D.G., Côrtes, F.H., Teixeira, S.L.M., dos Santos Silva, K., Hoagland, B., Grinsztejn, B., Veloso, V.G., Morgado, M.G. and Bello, G. (2017) Highly Divergent Patterns of Genetic Diversity and Evolution in Proviral Quasispecies from HIV Controllers. Retrovirology, 14, 29.

https://doi.org/10.1186/s12977-017-0354-5

[79] Klatt, N.R., Bosinger, S.E., Peck, M., Richert-Spuhler, L.E., Heigele, A., Gile, J.P., Patel, N., Taaffe, J., Julg, B., Camerini, D., Torti, C., Martin, J.N., Deeks, S.G., Sinclair, E., Hecht, F.M., Lederman, M.M., Paiardini, M., Kirchhoff, F., Brenchley, J.M., Hunt, P.W. and Silvestri, G. (2014) Limited HIV Infection of Central Memory and Stem Cell Memory CD4 ${ }^{+} \mathrm{T}$ Cells Is Associated with Lack of Progression in Viremic Individuals. PLoS Pathogens, 10, e1004345. 
https://doi.org/10.1371/journal.ppat.1004345

[80] de Groot, N.G. and Bontrop, R.E. (2013) The HIV-1 Pandemic: Does the Selective Sweep in Chimpanzees Mirror Humankind's Future? Retrovirology, 10, 53. https://doi.org/10.1186/1742-4690-10-53

[81] Hellmut,h J., Valcour, V. and Spudich, S. (2015) CNS Reservoirs for HIV: Implications for Eradication. Journal of Virus Eradication, 1, 67-71.

[82] Tully, D.C., Hjerrild, S., Leutscher, P.D., Renvillard, S.G., Ogilvie, C.B., Bean, D.J., Videbech, P., Allen, T.M., McKeating, J.A. and Fletcher, N.F. (2016) Deep Sequencing of Hepatitis C Virus Reveals Genetic Compartmentalization in Cerebrospinal Fluid from Cognitively Impaired Patients. Liver International, 36, 1418-1424. https://doi.org/10.1111/liv.13134

[83] Mathew, S., Faheem, M., Ibrahim, S.M., Iqbal, W., Rauff, B., Fatima, K. and Qadri, I. (2016) Hepatitis C Virus and Neurological Damage. World Journal of Hepatology, 8, 545-556.

[84] Sun, B., Abadjian, L., Rempel, H., Monto, A. and Pulliam, L. (2013) Differential Cognitive Impairment in HCV Coinfected Men with Controlled HIV Compared to HCV Monoinfection. Journal of Acquired Immune Deficiency Syndromes, 62, 190 196. https://doi.org/10.1097/QAI.0b013e31827b61f1

[85] Ingiliz, P., Martin, T.C., Rodger, A., Stellbrink, H.J., Mauss, S., Boesecke, C., et al. (2017) HCV Reinfection Incidence and Spontaneous Clearance Rates in HIV-Positive Men Who Have Sex with Men in Western Europe. Journal of Hepatology, 66, 282-287. https://doi.org/10.1016/j.jhep.2016.09.004

[86] Annequin, M., Lert, F., Spire, B. and Dray-Spira, R., ANRS-Vespa2 Study Group (2016) Increase in Unemployment over the 2000's: Comparison between People Living with HIV and the French General Population. PLoS ONE, 11, e0165634. https://doi.org/10.1371/journal.pone.0165634

[87] Holmberg, S. (CDC) (2016) Acute Hepatitis C Infection in Young Persons Who Use Drugs. Medscape. http://www.medscape.com/viewarticle/856569

[88] Kabiri, M., Jazwinski, A.B., Roberts, M.S., Schaefer, A.J. and Chhatwal, J. (2014) The Changing Burden of Hepatitis C Infection in the United States: Model-Based Predictions. Annals of Internal Medicine, 161, 170-180. https://doi.org/10.7326/M14-0095

[89] Platt, L., Easterbrook, Ph., Gower, E., McDonald, B., Sabin, K., McGowan, C., Yanny, I., Razavi, H. and Vickerman, P. (2016) Prevalence and Burden of HCV Co-Infection in People Living with HIV: A Global Systematic Review and Meta-Analysis. The Lancet Infectious Diseases, 16, 797-808. https://doi.org/10.1016/S1473-3099(15)00485-5

[90] Petruzziello, A., Marigliano, S., Loquercio, G., Cozzolino, A. and Cacciapuoti, C. (2016) Global Epidemiology of Hepatitis C Virus Infection: An Up-Date of the Distribution and Circulation of Hepatitis C Virus Genotypes. World Journal of Gastroenterology, 22, 7824-7840. https://doi.org/10.3748/wjg.v22.i34.7824

[91] Foster, A.L., Gaisa, M.M., Hijdra, R.M., Turner, S.S., Morey, T.J., Jacobson, K.B. and Fierer, D.S. (2017) Shedding of Hepatitis C Virus into the Rectum of HIV-Infected Men Who Have Sex with Men. Clinical Infectious Diseases, 64, 284-288. https://doi.org/10.1093/cid/ciw740

[92] CDC, USA (2011) Sexual Transmission of Hepatitis C Virus among HIV-Infected Men Who Have Sex with Men-New York City, 2005-2010. Morbidity and Mortality Weekly Report, 60, 945-950.

[93] Kamarulzaman, A., Reid, S.E., Schwitters, A., Wiessing, L., El-Bassel, N., Dolan, K., 
Moazen, B., Wirtz, A.L., Verster, A. and Altice, F.L. (2016) Prevention of Transmission of HIV, Hepatitis B Virus, Hepatitis C Virus, and Tuberculosis in Prisoners. The Lancet, 388, 1115-1126. https://doi.org/10.1016/S0140-6736(16)30769-3

[94] Dolan, K., Wirtz, A.L., Moazen, B., Martial, N., Galvani, A., Kinner, St.A., Courtney, R., McKee, M., Amon, J.J., Maher, L., Hellard, M., Beyrer, Ch. and Altice, F.L. (2016) Global Burden of HIV, Viral Hepatitis, and Tuberculosis in Prisoners and Detainees. The Lancet, 388, 1089-1102. https://doi.org/10.1016/S0140-6736(16)30466-4

[95] RKI (2015) Weiterer Starker Anstieg der Syphilis bei MSM in Deutschland im Jahr 2014 (Article in German only). Epidemiological Bulletin, 49, 515-528.

[96] de Voux, A, Kidd, S., Grey, J.A., Rosenberg, E.S., Gift, Th.L., Weinstock, H. and Bernstein, K.T. (2017) State-Specific Rates of Primary and Secondary Syphilis Among Men Who Have Sex with Men-United States, 2015. Morbidity and Mortality Weekly Report, 66, 349-354. https://doi.org/10.15585/mmwr.mm6613a1

[97] Lambert, C.T., Sandesara, P.B., Hirsh, B., Shaw, L.J., Lewis, W., Quyyumi, A.A., Schinazi, R.F., Post, W.S. and Sperling, L. (2016) HIV, Highly Active Antiretroviral Therapy and the Heart-A Cellular to Epidemiological Review. HIV Medicine, 17, 411-424. https://doi.org/10.1111/hiv.12346

[98] Eaton, E.F., Tamhane, A., Saag, M., Mugavero, M.J. and Kilgore, M. L. (2016) Cost Considerations in the Current Antiretroviral Era. AIDS, 30, 2115-2119.

https://doi.org/10.1097/QAD.0000000000001120

[99] Zucchetto, A., Virdone, S., Taborelli, M., Grande, E., Camoni, L., Pappagallo, M., Regine, V., Grippo, F., Polesel, J., Dal Maso. L., Suligoi, B., Frova, L. and Serraino, D. (2016) Non-AIDS Defining Cancer Mortality: Emerging Patterns in the Late HAART Era. Journal of Acquired Immune Deficiency Syndromes, 73, 190-196. https://doi.org/10.1097/QAI.0000000000001033

[100] Centers for Disease Control and Prevention (2016) Reported STDs at Unprecedented High in the U.S. Press Release.

https://www.cdc.gov/nchhstp/newsroom/2016/std-surveillance-report-2015-press-r elease.html

See also: CDC (2016) Sexually Transmitted Disease Surveillance 2015. U.S. Department of Health and Human Services, Atlanta.

[101] WHO, News Release (2016) WHO Report Warns Global Actions and Investments to End Tuberculosis Epidemic are Falling Far Short.

http://www.who.int/mediacentre/news/releases/2016/tuberculosis-investments-shor t/en/

[102] Auld, S.C., Brust, J.C., Mathema, B., Mthiyane, T., Ismail, N., Moodley, P., McDaniel, D., Allana, S., Gandhi, N. and Shah, N.S. (2016) HIV-Associated XDR TB Is Transmitted in Households and Hospitals in South Africa. Conference on Retroviruses and Opportunistic Infections, Boston, MA, 22-25 February 2016, Abstract No. 157.

http://www.croiconference.org/sessions/hiv-associated-xdr-tb-transmitted-househo $\underline{\text { lds-and-hospitals-south-africa }}$ 
Submit or recommend next manuscript to SCIRP and we will provide best service for you:

Accepting pre-submission inquiries through Email, Facebook, LinkedIn, Twitter, etc. A wide selection of journals (inclusive of 9 subjects, more than 200 journals)

Providing 24-hour high-quality service

User-friendly online submission system

Fair and swift peer-review system

Efficient typesetting and proofreading procedure

Display of the result of downloads and visits, as well as the number of cited articles Maximum dissemination of your research work

Submit your manuscript at: http://papersubmission.scirp.org/

Or contact wja@scirp.org 